\title{
DZIENNIKARSTWO JAKO MISJA. O EMIGRACYJNEJ PUBLICYSTYCE ZYGMUNTA NOWAKOWSKIEGO
}

\author{
Marcin LUTOMIERSKI (Toruń)
}

Zygmunt Nowakowski był jedną z czołowych postaci, by nie rzec: ikon, ,polskiego Londynu". Zaangażowaną postawą pisarską, wyrazistymi poglądami i szeroką działalnością organizacyjno-kulturalną współtworzył on, m.in. razem z Tymonem Terleckim, etos emigranta - który swój pobyt na obczyźnie pojmował jako formę sprzeciwu wobec porządku narzuconego podczas konferencji w Jałcie, a także rodzaj walki o niepodległą Polskę. Styl myślenia i zachowania Nowakowskiego trafnie oddają określenia samych emigrantów, którzy nazywali go „Rejtanem (na) emigracji” albo, żartobliwie, „emigrejtanem”, ,,syntetycznym Polakiem”, ,niezłomnym towarzyszem broni”, ,puklerzem w najcięższych chwilach",3, ,nieustraszonym szermierzem sprawy polskiej"4, „patriarchą emigracji politycznej”, czy wreszcie — „,nocnym stróżem Krakowa”6.

Poniższe refleksje stanowić będą próbę zilustrowania misyjności emigracyjnej publicystyki autora Lajkonika na wygnaniu. Już teraz pragnę zaznaczyć, że tej części spuścizny pisarza badacze poświęcili jak dotąd niewiele uwagi. Kreśląc sylwetkę twórczą Nowakowskiego, jego publicystyką mniej lub bardziej szczegółowo (choć nie

${ }^{1}$ S. S. Nicieja, Zygmunt Nowakowski - Rejtan na emigracji, Dekada Literacka 1992 nr 14 [on-line]. [Dostęp: czerwiec 2011]. Dostępny w WWW: http://dekadaliteracka.pl/index.php?id=792.

${ }^{2}$ S. Kossowska, Syntetyczny Polak, [w:] tejże, Galeria przodków, Warszawa 1991, s. 73.

${ }^{3}$ [M. Grydzewski] Silva, Silva rerum. Nowakowski i ,Wiadomości”, Wiadomości $1955 \mathrm{nr}$ 7(463), s. 5.

${ }^{4}$ Kronika. Zygmunt Nowakowski laureatem nagrody „Dziennika Polskiego”, Wiadomości $1951 \mathrm{nr}$ 48(296), s. 4.

${ }^{5}$ B. Czaykowski, B. Sulik, Polacy w W. Brytanii, Paryż 1961, s. 278.

${ }^{6}$ J. Rostworowski, Nocny stróż Krakowa. Zygmuntowi Nowakowskiemu w hołdzie, Wiadomości $1963 \mathrm{nr}$ 9(883), s. 1. 
w kontekście misyjności) zajmowali się jedynie Stanisław Sławomir Nicieja ${ }^{7}$, Marta Ziółkowska-Sobecka ${ }^{8}$, Rafał Habielski ${ }^{9}$ i Dorota $\mathrm{Heck}^{10}$, a niejako ,przy okazji” omawiania tradycji romantycznej w publicystyce i eseistyce XX-wiecznego wychodźstwa na temat felietonów „Rejtana emigracji” pisała Tatiana Olejnik ${ }^{11}$. Poza tym emigracyjna publicystyka Nowakowskiego nie doczekała się krajowych edycji — przez co nasza wiedza o jego pisarstwie jest wciąż niewystarczająca.

\section{Publicysta zaangażowany}

Krakowski publicysta, ale i pisarz, aktor, reżyser, doktor filologii polskiej Zygmunt Nowakowski (właściwie: Zygmunt Tempka) już w latach 30. XX w. był postacią powszechnie znaną. Wybitny felietonista „Ilustrowanego Kuriera Codziennego”, autor poczytnych powieści, z których Przylądek Dobrej Nadziei doczekał się piętnastu wydań i przekładów na sześć języków, dobry aktor i niekonwencjonalny reżyser w obawie (dodajmy: uzasadnionej) przed represjami ze strony okupantów opuścił Polskę w 1939 r. i nigdy już — mimo wielu zaproszeń — do niej nie powrócił. Jako wojenny uchodźca angażował się w działalność polityczną, czego wymownym przykładem może być chociażby członkostwo w Radzie Narodowej (namiastce parlamentu polskiego na obczyźnie). Z czasem jednak coraz bardziej oddalał się od czynnej polityki, za to nieprzerwanie pozostawał aktywnym publicystą. Jego wysiłkom pisarskim zdawały się przyświecać dwie zasadnicze idee: walka o niepodległą i suwerenną Polskę oraz ratowanie zagrożonej tak w kraju, jak i na obczyźnie polskiej kultury. Pisarz był zdecydowanym przeciwnikiem porozumienia $\mathrm{z}$ władzami sowieckimi, zajmując tym samym stanowisko opozycyjne wobec rządu Sikorskiego i jego sojuszników. Wypowiedzi Nowakowskiego na łamach londyńskich „Wiadomości Polskich, Politycznych i Literackich” uznano za wyjątkowo szkodliwe dla jedności alianckiej i 12 lutego 1944 r. Brytyjskie Ministerstwo Informacji doprowadziło do zamknięcia tygodnika.

W niniejszym artykule interesuje mnie jedynie powojenny dorobek Nowakowskiego, a trzeba to wyraźnie podkreślić, że autor był wówczas niezwykle płodnym publicystą. Publikował na łamach wielu emigracyjnych czasopism, takich jak m.in.: „Wiadomości” (Londyn), „Dziennik Polski” przemianowany potem na „Dziennik Polski i Dziennik Żołnierza” (Londyn), „Nowy Świat” (Nowy Jork), „Dziennik Polski” (Detroit) czy „Lwów i Wilno” (Londyn). Mimo że wypowiadał się zarówno w formie artykułów publicystycznych, wspomnieniowych, w formie szkiców i recenzji (nie tylko publikowanych w prasie, lecz także wygłaszanych przed mikrofonem Radia Wolna Europa), to jego ulubionym gatunkiem wciąż pozostawał felieton. Warto jeszcze nad-

\footnotetext{
${ }^{7}$ Zob.: S. S. Nicieja, Zygmunt Nowakowski.

${ }^{8}$ Zob.: M. Ziółkowska-Sobecka, Zygmunt Nowakowski — pisarz zapomniany, Studia i Materiały Polonistyczne 1994 nr 1, s. 63-85.

${ }^{9}$ Zob.: R. Habielski, Essentia Polona albo niezłomny. O Zygmuncie Nowakowskim, [w:] „Wiadomości” i okolice. Szkice i wspomnienia, red. i oprac. M. A. Supruniuk, t. II, Toruń 1996, s. 73-88.

${ }^{10}$ Zob.: D. Heck, Zygmunt Nowakowski jako pisarz zapomniany, [w:] Proza polska na obczyźnie. Problemy - dyskursy - uzupetnienia, red. Z. Andres, J. Pasterski, A. Wal, t. I, Rzeszów 2007, s. 344-355.

${ }^{11}$ Zob.: T. Olejnik, „Nakaz i nadzieja. Tradycja romantyczna w publicystyce i eseistyce emigracji niepodległościowej lat 1939-1955", rozprawa doktorska, Uniwersytet Mikołaja Kopernika, Toruń 2002, mps.
} 
mienić, że — jak mówi badacz londyńskich „Wiadomości” Rafał Habielski — publicystyka stanowiła jedyne źródło utrzymania „niezłomnego emigranta" ${ }^{, 2}$.

Teksty Nowakowskiego cieszyły się zainteresowaniem i uznaniem w szerokich kręgach emigracji niepodległościowej nie tylko ze względu na treść, ale i styl czy postawę autora, którego na emigracji szanowali nawet ideowi przeciwnicy. Zachowało się niemało świadectw odbioru publicystyki Nowakowskiego, głównie w postaci listów do redakcji czasopism publikujących jego artykuły ${ }^{13}$. Wydaje się jednak, że najtrafniej rzecz ujął Edward Raczyński w słowie wstępnym do Lajkonika na wygnaniu, gdzie wypowiadając zgodną opinię wielu emigrantów, konstatował:

Jakie miano Historia nada dzisiejszemu uchodźstwu, nie wiemy. Odniesie się do nas pobłażliwie wtedy tylko, jeśli nasz narodowy obowiązek spełnimy do końca. Zygmunt Nowakowski ani na chwilę nie pozwala nam o tym zapomnieć. Zna dobrze nasze kłopoty a niekiedy wątpliwości, i podsuwa trafne rozwiązania. Zachęca, poucza, prosi. Kiedy tego potrzeba, umie przemówić jak wnikliwy i surowy głos sumienia. Nikt także lepiej od niego nie wyraża tego, co odczuwamy i nie wygarnia słów prawdy komu należy. A jak to wszystko jest powiedziane. Nie po bakałarsku, ale tak jak to potrafi tylko pisarz z Bożej łaski, wymownie, wzruszająco a przy tym zabawnie. Humor Nowakowskiego jest najprzedniejszej próby, ostry jak brzytwa choć nie zjadliwy. Czyż można się dziwić, że otoczyła go powszechna wdzięczność i sympatia? ${ }^{14}$.

Przyjrzyjmy się zatem najważniejszym aspektom misyjności wypowiedzi autora Z księgi zażaleń pielgrzymstwa polskiego, uporządkowanym według kryterium problemowego jego tekstów.

\section{Zadania emigracji}

Jednym z problemów najczęściej obecnych w rozważaniach Nowakowskiego były zadania emigracji niepodległościowej. Przy tej okazji publicysta odwoływał się zwykle do „wielkiej poprzedniczki”, sugerując tym samym, że tradycja romantyczna jest swoistym fundamentem, podglebiem i punktem odniesienia dla nowego wychodźstwa politycznego. Było to istotne przede wszystkim ze względu na fakt, że zakończenie działań militarnych w Europie i przywrócenie państwa polskiego na arenę międzynarodową mocno podważyło sens istnienia wojennego uchodźstwa - tak pod względem formalnym ${ }^{15}$, jak ideowym. Na marginesie przypomnę tylko, że mimo niekorzystnych okoliczności tysiące Polaków dobrowolnie bądź też w obliczu realnej groźby represji

${ }^{12}$ Zob.: R. Habielski, Essentia Polona albo nieztomny, s. 85.

13 Wymownym świadectwem odbioru twórczości Nowakowskiego była zorganizowana w szerokich kręgach emigracyjnych zbiórka pieniędzy, dzięki której zakupiono schorowanemu pisarzowi dom, nieprzypadkowo nazwany „Oblęgorkiem”.

${ }^{14}$ E. Raczyński, Przedmowa, [do:] Z. Nowakowski, Lajkonik na wygnaniu. Felietonów sto i jeden (1950-1962), Londyn 1963, s. 7 (dalej: tytuł felietonu, [w:] $L W$ i numer strony).

15 Rok 1945 okazał się przełomowy w dziejach polskiego uchodźstwa, stającego się odtąd emigracją. Przyniósł on nie tylko zakończenie działań wojennych w Europie, lecz także nowe, bardzo niekorzystne dla Polaków i sprawy polskiej, ustalenia polityczne przyjęte przez aliantów na konferencjach w Jałcie (luty) i Poczdamie (lipiec-sierpień). Ponadto w lipcu 1945 r. nastąpiło cofnięcie uznania rządowi Tomasza Arciszewskiego przez Stany Zjednoczone i Wielką Brytanię. Zarówno premier rządu polskiego w Londynie, jak i ówczesny prezydent Rzeczpospolitej Polskiej na uchodźstwie, Władysław Raczkiewicz, zajęli w swoich oświadczeniach i orędziach stanowiska zdecydowanie odrzucające i potępiające uchwały podjęte bez wiedzy oraz zgody Polaków. 
(ze strony władz polskich lub sowieckich) zdecydowało się pozostać na obczyźnie. Liczne i rozproszone skupiska dawnych wychodźców zasilali także uciekinierzy z Polski Ludowej. Wśród rodaków, którzy swoje osobiste decyzje łączyli ze sprawami ideowymi i politycznymi następował proces uzyskiwania samoświadomości. Stąd też w obliczu powojennego chaosu konieczne było wyznaczenie klarownych zadań dla nowej emigracji politycznej, w czym ważką rolę odegrała spuścizna Wielkiej Emigracji. Zadania wojennego i powojennego uchodźstwa Nowakowski pojmował bardzo romantycznie, stawiał bowiem wymagania — żeby nie tylko zachować istotę narodowości i nienaruszoną treść Polski, lecz także wzbogacać tę treść o nowe wartości, których Polacy w kraju nie mogą tworzyć ze względu na istniejące warunki polityczne ${ }^{16}$. Charakterystyczne dla Nowakowskiego było również to, że o zadaniach emigracji potrafił mówić w tonie żartobliwym, bez romantycznego patosu, np.:

Trzeba koniecznie wylegitymować się czymś przed Krajem. Paczki? Najlony? Oczywiście, należy wysyłać jak najwięcej, ale nie samą „Nescafe” człowiek żyje. Mniemam, że nasi rodacy w Polsce żyją także wiarą i nadzieją. Ośmielam się przypuszczać, że trochę, troszeczkę wierzą w nas. Nie zanadto, ale wierzą, jak można przypuszczać na podstawie listów i rozmów. Wyobrażają sobie, że emigracja myśli nie tylko o brzuchu, ale i o duchu. Oby się nie zawiedli! $!^{17}$.

Należy podkreślić, że choć Nowakowski wypowiadał się o zadaniach wychodźstwa na różne sposoby, zawsze robił to $\mathrm{z}$ właściwą sobie pasją. Powracał przy tym do kwestii fundamentalnych, czyli istoty i celu emigracji politycznej, którą wyraźnie odróżniał od emigracji zarobkowej ${ }^{18}$. Ostrze krytyki nie omijało również emigracyjnych polityków (,zawodowców”), którym zarzucał utożsamianie ojczyzny z własną partią, nadmierną kłótliwość oraz brak troski o ojczyznę ${ }^{19}$.

Broniąc ideowego oblicza wychodźstwa, publicysta nie cofał się przed napiętnowaniem emigrantów przyjmujących obywatelstwo kraju osiedlenia. Nowakowski oskarżał ich o chęć ułatwienia sobie życia na obczyźnie - za pomocą ulg, zniżek i ,pierwszeństwa w ogonku”, co w konsekwencji prowadzić miało do przekształcenia emigracji politycznej w zarobkową. Uzyskanie nowego paszportu felietonista traktował jako wyparcie się polskości i zdradę ojczyzny. Zastrzegał jednak, że nie ma tu na myśli osób, które znalazły się w sytuacji przymusowej i decydowały się na ów krok, by ratować od głodu najbliższych. Renegatom wytykał zaś Nowakowski opuszczanie Polski i Polaków ,cichaczem, po ciemku, na palcach” oraz dobrowolne stawanie się w nowym państwie obywatelami drugiej klasy. Ponadto z emfazą przypominał:

Nie jest się Polakiem z przypadku. Nie wygrywa się ojczyzny na loterii. Sądzę, że jest się Polakiem z honoru, z każdego uderzenia serca, które mówi za nas, że gdyby nam przyszło urodzić się po raz drugi, czy dziesiąty, czy setny, chcielibyśmy urodzić się Polakami. [...] Polska żyje w sferze świadomości i uczucia. Chwilowo nie ma jej gdzie indziej. Ale jutro może być w sferze dostępnej naszym zmysłom. [...]

Kto chce być Polakiem naprawdę, musi wyciągnąć wszystkie konsekwencje, musi wypić puchar przedziwnej goryczy, ale może, może na samym dnie — to nie jest rzecz absolutnie pewna! — znajdzie nie gorycz, lecz słodycz powrotu ${ }^{20}$.

${ }^{16}$ Por.: Przemówienie dr. Z. Nowakowskiego na wiecu manchesterskim, który zgromadzit osiem tysięcy Polaków, [w:] LW, s. 187-188.

${ }^{17}$ Po prośbie, [w:] LW, s. 201.

${ }^{18}$ Zob.: tenże, O czym się nie mówi, Wiadomości 1948 nr 38(129), s. 1.

${ }^{19}$ Zob. tamże.

${ }^{20}$ Tenże, Poloniae adscripti, Wiadomości 1949 nr 45(188), s. 1. 
Nowakowski był więc zwolennikiem trwania, choćby długiego, w gotowości na bliższy lub dalszy powrót do kraju, ale tylko pod warunkiem, że będzie on całkowicie suwerenny. Taką postawę winni jego zdaniem przyjąć polscy wychodźcy, którzy pobyt na obczyźnie wybrali świadomie, w przeciwieństwie do godnych pogardy i nienawiści Polaków i emigrantów ,z przypadku”.

Poza walką o niepodległość Kraju (pisanego tak przez wielu emigrantów) i przyjmowaniem jej bolesnych nieraz konsekwencji głównym zadaniem emigracji była także — według Nowakowskiego - pamięć o rodakach dręczonych w sowieckich łagrach (na marginesie dodam tylko, że ów postulat wypływał z tradycji Mickiewiczowskiej). „Któż upomni się o tych biedaków, jeśli nie my?" tekstach „niezłomny emigrant”, zsyłki na Sybir komentował zaś następująco: „Ks. Piotr oślepłby na ich widok i wolałby nie mieć «widzenia»"22. Ponadto Nowakowski razem z Ferdynandem Goetlem, Józefem Mackiewiczem i innymi pisarzami emigracyjnymi niestrudzenie walczył piórem o prawdę na temat zbrodni w Katyniu ${ }^{23}$.

\section{Wobec emigracyjnych trosk dnia codziennego}

Mimo zaangażowania w sprawy ideowe czy nawet ideologiczne Nowakowski nie pozostawał obojętny na tzw. życie codzienne emigracji. Z prawdziwą empatią pisał bowiem również o takich kwestiach jak warunki materialne polskich obozów Polskiego Korpusu Przysposobienia i Rozmieszczenia, szpitali ${ }^{24}$, szkół, świetlic czy bibliotek ${ }^{25}$. Zwracał również uwagę na niebezpieczne tendencje językowe, panujące wśród emigrantów i ostrzegał ich przed zanikiem pięknej polszczyzny ${ }^{26}$.

Jako jeden z niewielu emigracyjnych publicystów Nowakowski dość często podejmował temat przykry i niejako wstydliwy, uczulał mianowicie na sytuację materialną mieszkańców obozów PKPR, a nade wszystko - ich kondycję psychiczną. Stąd też w trudnym dla emigracji okresie powojennego chaosu i braku nadziei, postulował, by do obozów byłych żołnierzy (obecnie członków PKPR) — ,[...] pod blaszane strzechy beczek śmiechu, pod dziurawe dachy hosteli, do ponurych obozów odosobnienia, których lokatorzy zapominają powoli, że są Polakami"27, trafiły utwory Mickiewicza, który:

[...] może ich nauczyć Polski hurtem. Mickiewicz jest pełen Polski. [...] Ktoś, kto sobie odświeży lekturę Mickiewicza, albo ktoś, kto Mickiewicza przeczyta po raz pierwszy w życiu, nie będzie czuł się tak bardzo odosobniony, nie będzie tak bardzo samotny, tak pozbawiony Polski, choćby nawet musiał przebywać jeszcze przez czas dłuższy w najbardziej ponurym obozie odosobnienia ${ }^{28}$.

Szczególną troską Nowakowski otaczał młode pokolenie (zwłaszcza na emigracji, choć nie zapominał o dzieciach i młodzieży w kraju). Niejednokrotnie uczulał na kwestię wychowania młodego pokolenia w polskości — zastanawiając się przy okazji nad

${ }^{21}$ Do Jego Magnificencji Rektora UJ, prof. dra Tadeusza Lehr-Sptawińskiego w Krakowie, [w:] $L W$, s. 205.

\footnotetext{
${ }^{22}$ Zob.: tenże, De Muscovitis Commentariorum liber unus, Wiadomości 1949 nr 4(147), s. 1.

${ }^{23}$ Zob.: Czarna niedziela, [w:] LW, s. 206-210.

${ }^{24}$ Zob.: ,Degradacja”, [w:] LW, s. 36-40.

${ }^{25}$ Zob.: Testament Lazarza, [w:] LW, s. 188-192.

${ }^{26}$ Por.: Żargon pielgrzymstwa polskiego, [w:] LW, s. 59; Trzymaj linię, [w:] LW, s. 158-162.

${ }^{27}$ Tenże, Obozy odosobnienia, Wiadomości 1948 nr 50(141), s. 1.

${ }^{28}$ Tamże, s. 1.
} 
właściwymi metodami postępowania. Jednocześnie wierzył, że najmłodsze pokolenie rodaków na obczyźnie może odegrać znaczącą rolę oraz, że to ono będzie kultywowało polskość i niepodległość. Dlatego stawał w obronie efemerycznych często pisemek redagowanych przez emigracyjnych skautów i harcerzy z całego świata, ponieważ widział w nich ,,jakiś ułamek wiedzy o Polsce"29.

\section{Przeciw komunistycznej władzy}

Nowakowski deklarował solidarność z Polakami pozostającymi w ojczyźnie (wiemy też, że wspierał ich m.in. wysyłając różnego typu paczki, głównie z lekarstwami), a zarazem bardzo wyraźnie potępiał działania władz Polski Ludowej (notabene, pisanej zawsze w cudzysłowie, podobnie jak ,rząd” warszawski). Jawnie i zdecydowanie występował przeciwko narzuconemu siłą porządkowi, demaskował przekupnych polityków, ostrzegał przed zdrajcami i osobami takimi jak Bolesław Bierut. Najczęściej jednak piętnował służalczość krajowych artystów ${ }^{30}$. Szczególnie krytyczne, ironiczne, polemiczne, a niekiedy nawet zjadliwe uwagi kierował pod adresem poetów takich jak Julian Tuwim, Jarosław Iwaszkiewicz, Jan Brzechwa czy Władysław Broniewski. Nie bez emocji pisał Nowakowski o świętowaniu w Polsce 30. rocznicy istnienia Związku Sowieckiego, kiedy to:

[...] otwarły się w Kraju wszystkie kanały i wszystkimi rynsztokami niczym rozpalona lawa, popłynęła wazelina. W tej powodzi akademii, manifestacji, obchodów, w tym wyciu szakalów, w tym zgodnym akordzie serwilizmu, rzeczą najbardziej obrzydliwą jest głos Tuwima ${ }^{31}$.

Publicysta zarzucił mu nikczemność i „chorobliwą egzaltację w świństwie”, sugerując zarazem, by spróbował napisać szopkę polityczną w stylu dawnym, przedwojennym. Wypowiedź Tuwima na cześć ZSSR Nowakowski podsumował określeniem: ideał upodlenia. W innym miejscu zaś przypomniał, że Rosjanie upadlają tylko tych, którzy sami chcą się upodlić, oraz że ludzie tacy jak Julian Tuwim, Jarosław Iwaszkiewicz czy nawet Aleksander Janta-Połczyński, policzkują wyłącznie samych siebie, z własnej i nieprzymuszonej woli ${ }^{32}$.

Interesując się zarówno problemami kulturowymi, jak i gospodarczymi, „Rejtan emigracji” nieustępliwie walczył z różnymi formami propagandy rządu, który — tak jak wielu emigrantów — nie nazywał polskim, tylko warszawskim. W sposób nader emocjonalny odpowiadał na hasła nowej władzy, demaskując jej kłamstwa stwierdzeniami typu:

Nęca nas i wabią, wołając: „Budujcie razem z nami nasz polski, własny, cały dom!”. Nieprawda! Ten dom nie jest ani polski, ani własny, ani cały. Dokąd wrócić ma Polak, który urodził się we Lwowie albo w Krzemieńcu, w Wilnie albo Nowogródku? Polska bez Lwowa i Wilna nie jest cała. Odrąbano od niej dwa miasta, które są jak serce i dusza naszej Ojczyzny. Kto dzisiaj wraca, ten godzi się z utratą Lwowa i Wilna, my zaś nigdy się $\mathrm{z}$ tą utratą nie pogodzimy ${ }^{33}$.

Konsekwencją takiej postawy był zdecydowany sprzeciw Nowakowskiego wobec ogłaszanej przez komunistów propozycji tzw. amnestii. Już samo słowo amnestia budziło

\footnotetext{
${ }^{29}$ Tenże, Polska młoda, Wiadomości 1949 nr 18(161), s. 1.

${ }^{30}$ Zob.: Pańszczyzna, [w:] LW, s. 83-87.

${ }^{31}$ Tenże, Kwiatki polskie Tuwima, Wiadomości 1947 nr 49(88), s. 3.

${ }^{32}$ Zob.: tenże, O pochodzeniu gatunków, Wiadomości 1949 nr 2/3(145/146), s. 2.

${ }^{33}$ Tenże, Przemówienie dr. Z. Nowakowskiego, s. 185.
} 
odrazę felietonisty, który nazwał je nikczemnym, karczemnym, plugawym, nędznym i ordynarnym. Godzić się na nią mógł tylko człowiek pozbawiony świadomości narodowej, człowiek słaby, znużony śmiertelnie, człowiek bez wiary i zobowiązań większych niż indywidualne. Nowakowski twierdził jednak, że takich ludzi nie potępia, ale ich żałuje. Nie uznawał bowiem kompromisu powrotu, który nazywał ,splunięciem w lustro" ${ }^{\text {" }}$.

Wspomnieć jeszcze należy inne przykłady walki publicysty z pozorami, stwarzanymi przez władze ,pojałtańskiej Polski”, jak chociażby obnażanie działalności krajowej cenzury ${ }^{35}$ czy wskazywanie absurdalnych kontrastów gospodarki żywnościowej ${ }^{36}$, co jednak wcale nie wykluczało podziwu Nowakowskiego dla występu zespołu Mazowsze, oddelegowanego przez komunistyczne władze do Londynu w celach propagandowych $^{37}$, albo zachwytu nad filmem Krzyżacy w reżyserii Aleksandra Forda ${ }^{38}$.

\section{Napominanie państw Zachodu}

Publicystyka Nowakowskiego zawierała także sporo krytycznych uwag pod adresem Brytyjczyków i Amerykanów, a ściślej: ich władz. Najkrócej rzecz ujmując, można powiedzieć, że - po pierwsze - pisarz niestrudzenie przypominał Zachodowi o udziale Polaków w minionej wojnie, o ich walce $z$ systemami totalitarnymi ${ }^{39}$. Jednocześnie zachęcał rodaków do przygotowania książki tyczącej walk polskich żołnierzy na frontach II wojny światowej.

Po wtóre, podkreślał Nowakowski prawo Polski do utraconych ziem wschodnich, których nie mogą zastąpić tereny poniemieckie.

Nie ma i nie może być żadnego odszkodowania za Lwów i Wilno ${ }^{40}$ — konstatował felietonista. Jest to tak, jakby zbir mówił do matki, że wprawdzie zabił jedno jej dziecko, ale nie powinna się tym denerwować, gdyż prawdopodobnie będzie miała drugie dziecko, może jeszcze ładniejsze. Nie ma takiej wagi, która by pomieściła na jednej szali Wrocław i Szczecin, na drugiej Lwów i Wilno. Można ważyć połcie słoniny lub worki $\mathrm{z}$ żytem, ale nie miasta, nie ziemie, nie honor ${ }^{41}$.

Kresy Wschodnie, symbolizowane przez dwa zasłużone dla kultury miasta, stanowiły zdaniem rodowitego krakowianina wartości niedające się niczym zastąpić, były po prostu nieodłączną częścią Polski. Z kolei nabytki północne i zachodnie traktował Nowakowski jako słuszne, ale jedynie częściowe odszkodowanie — nie za Lwów i nie za Wilno, tylko za straszliwe zbrodnie niemieckie, których ofiarą padła Polska.

Innym stałym wątkiem uwag felietonisty kierowanych do rządów państw zachodnich było przypominanie o barbarzyństwie wojsk niemieckich i sowieckich. Pisarz występował tym samym przeciw obojętności powojennego świata, który zapominał o niedawnych okrucieństwach, przez co, zdaniem Nowakowskiego, istniała obawa powtórzenia tragedii ${ }^{42}$. Publicysta niezwykle krytycznie odnosił się do wyroków Mię-

\footnotetext{
${ }^{34}$ Zob.: tenże, Amnestia — słowo nikczemne, Wiadomości 1947 nr 16(55), s. 1.

${ }^{35}$ Zob.: Organizacja B-k., [w:] $L W$, s. 27-31.

${ }^{36}$ Zob.: Żreć, nie umierać!, [w:] LW, s. 258-262.

${ }^{37}$ Zob.: Klaskaniem mając obrzękte prawice..., [w:] LW, s. 233-237.

${ }^{38}$ Zob.: Wielka choragiew, [w:] LW, s. 447-451.

${ }^{39}$ Zob.: Czerwone maki, [w:] LW, s. 60-64.

${ }^{40}$ Tenże, Nie za Lwów i nie za Wilno!, Wiadomości 1947 nr 38(77), s. 1.

${ }^{41}$ Tamże, s. 1.

${ }^{42}$ Dziś nie będziemy się śmiali, [w:] LW, s. 391-395.
} 
dzynarodowych Trybunałów Wojskowych, ,[...] gdzie w handel poszły takie towary norymberskie, jak prawda, sprawiedliwość, wstyd" "43, a samą Norymbergę traktował jako symbol nowego, niesprawiedliwego ładu na świecie.

Po czwarte zaś, autor Wynajętych „Polaków” nie wahał się przed potępieniem polityki zagranicznej państw, które utrzymują przyjazne stosunki dyplomatyczne z ,przedstawicielstwami zbiorowej zbrodni, zwanej Rosją sowiecką" "44; takie postępowanie nazywał on „pospolitym świństwem”. Ostrze krytyki Nowakowskiego nie omijało także Watykanu. Komentując na przykład protest stolicy apostolskiej przeciwko uwięzieniu kardynała Józsefa Mindszentyego przez komunistyczne władze Węgier, uznawał tę reakcję za jak najbardziej słuszną, lecz wielce spóźnioną. Przypominał bowiem, że prymas Węgier jest takim samym sługą bożym, jak ci zwykli księża, których skazuje sąd sowiecki w Polsce, a których nikt nie bierze w obronę. Publicysta zwracał też uwagę na fakt, że papież nie protestował, kiedy na przykład starego i schorowanego biskupa płockiego Antoniego Nowowiejskiego umieszczono, a następnie zadręczono w obozie koncentracyjnym. Poza tym Watykan nie tylko milczał przez wiele lat, ale i sam ,,[...] brał żywy udział w kasowaniu polskich diecezji, powierzając je Niemcom" ${ }^{45}$. Mówiąc o czekaniu w bólu i męce, Nowakowski z goryczą wypominał papieżowi brak potępienia prześladowców, którzy we wrześniu 1939 r. dokonali agresji na Polskę. Nie bez żalu wreszcie konstatował:

Krzyk w sprawie prymasa Węgier każe nam myśleć o głuchym milczeniu, z jakim świat katolicki odniósł się do największej zbrodni w dziejach, więc do straszliwego mordu katyńskiego ${ }^{46}$.

Tymczasem według emigracyjnego felietonisty kardynalna zasada sprawiedliwości w duchu chrześcijańskim polega na braniu w obronę każdego człowieka — bez względu na przynależność stanową (duchowny, świecki), narodowościową, rasową czy religijną. Nauka Chrystusa ogarnia bowiem:

[...] wszystkich bez wyjątku nie czyniąc różnicy między białymi, żółtymi, czarnymi, między sytym a głodnym, między chorym a zdrowym. Ta nauka jest jak płaszcz, może nie purpurowy, ale za to ogromny, płaszcz miłości, płaszcz łaski, płaszcz sprawiedliwości. Ma do niego prawo każdy człowiek ${ }^{47}$.

\section{Styl pisania}

Poznaliśmy już zarys treści oraz wymowę felietonów Zygmunta Nowakowskiego. A jak w kontekście dziennikarskiej misji przedstawiał się wspominany niejednokrotnie jego styl pisania? Rafał Habielski podsumowuje ową kwestię następująco:

Publicystyka Nowakowskiego, ta pisana przed i po wojnie, wzrusza obecnością sympatycznych anachronizmów - patosu i wybujałego sentymentalizmu. Zwraca zarazem uwagę niewątpliwymi przymiotami, przenikliwością i jasnością postrzegania rzeczywistości oraz umiejętnością docierania do istoty zagadnień zajmujących autora ${ }^{48}$.

\footnotetext{
${ }^{43}$ Tenże, Towary norymberskie, Wiadomości 1946 nr 29, s. 1.

${ }^{44}$ Kawior w korycie, [w:] $L W$, s. 68.

${ }^{45}$ Tenże, Kardynalna sprawa, Wiadomości 1949 nr 12/13(155/156), s. 3.

${ }^{46}$ Tamże, s. 3.

${ }^{47}$ Tamże.

${ }^{48}$ R. Habielski, Essentia Polona albo niezłomny, s. 74.
} 
Na potrzeby niniejszego artykułu pozwolę sobie zaakcentować dwie najbardziej znaczące cechy wypowiedzi emigracyjnego felietonisty, a mianowicie: słownictwo oraz nasycony ironią humor. Zasób leksykalny Nowakowskiego był nader bogaty, gdyż składały się na niego zarówno słowa dawne, przestarzałe, jak i wtrącenia z języka łacińskiego czy angielskiego. Przede wszystkim jednak publicysta posługiwał się słownictwem o wysokim natężeniu ekspresji (w tym również wyrazami dosadnymi), starając się przy tym wyrażać za pomocą oryginalnych epitetów i metafor. Nie dziwi zatem fakt, że zamiast używać powszechnych określeń typu zdrajca, wróg, nieprzyjaciel, częściej wolał mówić np. lokaj, fagas o pańszczyźnianej duszy, płotka, kolosalny szubrawiec, czerwony złodziej, kołtun czerwony, ciura obozowy czy płastuga emigracyjna pospolita - by wymienić tylko niektóre nazwy. Dodać od razu należy, iż takie słownictwo nie było ,zarezerwowane” jedynie dla przedstawicieli nowej władzy w Polsce, lecz także - jej rzeczywistych lub domniemanych zwolenników na emigracji. Częściej jednak podejmował Nowakowski polemiczną walkę (bo w takich kategoriach rzecz należałoby ujmować) z krajowymi politykami, artystami czy naukowcami. Dla przykładu powiedzmy, że historyków, autorów albumu o tysiącletniej historii Polski (Thousand Years of Polish History), którzy całkowicie pominęli kulturotwórczą rolę Kresów Wschodnich publicysta nazwał szajką i oszustami, po czym zakończył felieton mocnymi słowami:

Sądzę, że oni, ci trzej członkowie szajki golą się niekiedy. A jeżeli golą się, tedy muszą widzieć swe twarze w lustrze. Czy też czasami bierze ich ochota, by napluć? Uczeni! Profesorowie uniwersytetu $!^{49}$.

Realizowanie przez Nowakowskiego misji nie wykluczało obecności subtelnego, a zarazem mocno ironicznego humoru, który trafnie oddaje następująca uwaga do obchodzonego w kraju roku jubileuszowego Kopernika:

Obyśmy przy tej sposobności nie dowiedzieli się, że Kopernik na dobrą sprawę był rodowitym Rosjaninem i pochodził z Tuły, gdzie jego przodkowie od stuleci zajmowali się wyrobem samowarów z miedzi. W ogóle Nikołaj Nikołajewicz Kopiernik. Babka astronoma była Tatiana Iwanowna Rokossowskaja.

Może na tym nie skończy się jubileusz i dowiemy się, że wprawdzie Kopernik wydrukował dzieło $O$ obrotach ciał niebieskich w 1543 roku, ale Stalin uprzedził go o dobrych kilkadziesiąt lat wyraziwszy te same myśli poprawnie, według kanonów dialektyki marksistowskiej ${ }^{50}$.

Zabawne w formie, choć poważne w wymowie, bywały niekiedy felietonowe recenzje Nowakowskiego, zwłaszcza tych książek, które zostały napisane w duchu komunistycznej propagandy. By uniknąć nadmiernej egzemplifikacji niniejszych rozważań podam tylko dość oryginalny, stylizowany na staropolski, tytuł tekstu poświęconego wydanej w Zurychu książce Zofii Kossak (Das Antlitz der Mutter. Bilder und Gedanken zur Geschichte Polens). Brzmi on następująco: Forteca kłamstwa mądrym dla memoryjatu, idyjotom dla nauki, politykom dla praktyki, melancholikom dla rozrywki erygowana albo Hitler i Stalin jako narzędzie stusznego gniewu Niebios w nabożnej książe Imci Pani Zofiji kunsztownie wystawieni ${ }^{51}$.

\footnotetext{
${ }^{49}$ Gaude Mater Polonia, [w:] LW, s. 370-371.

${ }^{50}$ Kopernik Volksdeutschem, [w:] LW, s. 104.

${ }^{51}$ Zob.: Wiadomości 1949 nr 41(184), s. 3.
} 


\section{Résumé}

Podsumowując dotychczasowe rozważania, można stwierdzić, że misyjność dziennikarstwa Nowakowskiego polegała głównie na przyjęciu postawy nonkonformistycznej, służbie sprawie polskiej, bezkompromisowej walce z tymi, których autor uznawał za jej wrogów, a także na obronie rodzimej kultury. Warto jednak podkreślić, że publicystyka Lajkonika na wygnaniu była w znacznej mierze odpowiedzią na przemiany w powojennej Polsce i nieustępliwą walką z komunistyczną propagandą. Pomijam tu kwestię słuszności obserwacji i wniosków emigracyjnego felietonisty, pragnę tylko zauważyć, iż jego wypowiedzi wynikały - wbrew temu, co się powszechnie o nim i ,polskim Londynie” sądzi — z zainteresowania sprawami krajowymi, o których Nowakowski czerpał wiedzę zarówno z osobistych listów, lektury krajowej prasy, jak i audycji Polskiego Radia.

Refleksja nad publicystyką „Rejtana emigracji” nasunąć również może takie oto pytanie: czy Nowakowski-dziennikarz, który z pasją realizował swoją misję, popełniał jakieś, by tak rzec, grzechy? Myślę, że tak, a do najważniejszych z nich zaliczyłbym nadmierny niekiedy polonocentryzm, tendencję do amplifikacji obrazu narodowej martyrologii oraz dość częste traktowanie władz państw totalitarnych jako reprezentantów i wyrazicieli postaw ich obywateli (co skutkowało pojawianiem się resentymentów publicysty do Niemców i Rosjan).

Pojmowanie dziennikarstwa jako misji wiązało się również z kontynuowaniem przez autora tradycji romantycznej, a zwłaszcza stylów zachowań Wielkiej Emigracji — obecnych tu implicite (w sposobie postrzegania ojczyzny, rozumienia polskości) i explicite (w aluzjach, cytatach, nawiązaniach tematycznych czy przywołaniach postaci romantyków). Nowakowski stale bowiem upominał się o moralność w polityce oraz poszanowanie godności człowieka i narodów, które znalazły się za żelazną kurtyną. Ponadto - odwołując się do takich kategorii jak patos, nostalgia, ale i humor wraz z ironią - tworzył oryginalny jak na owe czasy przekaz, za pomocą którego walczył o najważniejsze dla niego wartości, to znaczy wolną Polskę, honor i prawdę.

\section{JOURNALISM AS MISSION. ON THE ZYGMUNT NOWAKOWSKI'S EMIGRATION JOURNALISTIC WRITING}

The article, bringing a reflection on the journalistic writing of Z. Nowakowski after 1945, shows a few brief thematic threads of the writer's publicism, such as emigration's aims and tasks; everyday life; anticommunism; calling attention of Western countries on the current situation of emigrants; criticism of emigration for taking citizenship of the country of exile; combat with the propaganda of Warsaw's government; "Vatican's silence."

KEY WORDS: emigration; publicism; Z. Nowakowski; "Polish London”. 